\title{
THE LITHOLOGY-FACIES CHARACTER OF ALEURO-SANDY ROCKS OF PRODUCTIVE MEMBERS (HORIZONS) OF THE TOURNAISIAN STAGE OF THE LOWER CARBONIFEROUS OF THE MEHEDOVSKO-LUTSENKOVSKO-SVIRIDOVSKY STRUCTURAL KNOT
}

\section{V.A. Ivanyshyn}

\section{ЛІТОЛОГО-ФАЦІАЛЬНА ХАРАКТЕРИСТИКА АЛЕВРО-ПІЩАНИХ ПОРІД ПРОДУКТИВНИХ ПАЧОК (ГОРИЗОНТІВ) ТУРНЕЙСЬКОГО ЯРУСУ НИЖНЬОГО КАРБОНУ МЕХЕДІВСЬКО-ЛУЦЕНКІВСЬКО-СВИРИДІВСЬКОГО СТРУКТУРНОГО ВУЗЛА}

\section{В.А. Іванишин}

It has been determined, on the base of macro -and microscopical studies of the core of productive members (horizons) of the Tournaisian stagefrom sections of the Mehedovskaia well 1, Lutsenkovskaia well 4, Sviridovskaia wells 2, 3, 4, 5, that accumulation of the Tournaisian deposits took place under the circumstances of very frequent interchonge of the tectonic movement sign, that has been reflected on their structure, texture and mineral composition. The fragmental product of sandstones and aleurolites are unsorted and not pebble - shaped. It contains numerous prints of plants, stems, barks, carbonized substance and has various layerings. Sediments deposited mainly under the continental circumstances.

На підставі макро- і мікроскопічного вивчення керну з продуктивних пачок (горизонтів) турнейського ярусу в розрізах Мехедівської свердловини 1, Луценківської 4 і Свиридівських 2, 3, 4, 5 встановлено, що накопичення турнейських відкладів відбувалося в умовах дуже частої зміни знаку тектонічних рухів, що відбилося на їх структурі, текстурі і мінеральному складі. Уламковий матеріал пісковиків і алевролітів не відсортований і не обкатаний. Вони містять численні відбитки обвуглених решток рослин, стебел, кори, вуглисту речовину, мають різноманітну шаруватість. Осадки накопичувалися переважно в континентальних умовах.

Ключові слова: продуктивна пачка, структура, текстура, мінеральний склад, пісковик, алевроліт.

За О.М.Заварицьким [1] і Ю.А.Жемчужниковим [2] структурний і текстурний вигляд осадочних порід і їх якісні відміни створюються фізико-хімічними, біологічними і геологічними процесами, що відбуваються одночасно або в різний час. Будова порід зумовлюється такими факторами: 1) умовами осадконакопичення і речовинним складом осадка, зокрема уламкового матеріалу; 2) результатами життєдіяльності організмів; 3) кристалізацією аутигенних мінералів, які складають породу і утворюються за рахунок присутнього в ній матеріалу або речовин, які випадають з хімічних і колоїдних розчинів.

Вивчення структурних і текстурних особливостей осадочних гірських порід, їх вигляду і просторового розташування текстур є абсолютно необхідною основою для вирішення багатьох практичних завдань літології і палеогеографії, зокрема при пошуково-розвідувальних роботах на нафту і газ.

Автор статті вважає, що характер осадконагромадження залежить насамперед від палеотектонічних (геодинамічних) процесів, котрі охоплювали ту чи іншу ділянку регіону або регіон загалом. При діагенезі і епігенезі до них додаються хімічні, біологічні і кліматичні процеси. Всі вони в сукупності формують той тип породи, з яким ми стикаємося зараз.

Із сказаного випливає, що при комплексному вивченні геологічної будови територій потрібно, насамперед, проводити дослідження особливостей їх розвитку або палеотектонічні дослідження. Саме за такою схемою проведено науково-дослідні роботи на Мехедівській, Луценківській і Свиридівській площах, які тісно пов'язані між собою, а тому їх можна розглядати як єдиний структурний чи тектонічний вузол. Результати проведених тут палеотектонічних досліджень свідчать про переважне північно-східне простягання Мехедівської, Луценківської структур і північно-західне - Свиридівської. Природним їх продовженням $є$ літолого-фаціальна характеристика відкладів, головними рисами яких $€$ їх структура, текстура і речовинний склад.

Відклади турнейського ярусу в цьому вузлі розкриті Мехедівською свердловиною 1, Луценківською 4, Свиридівськими 2, 3, 4, 5 на глибинах 5418-5736, 5507-5842, 5632-5990, 5607-5931, 55925936, 5660-6018м відповідно. В них виділено продуктивні пачки - горизонти Т-1, Т-2, Т-3, Т-4в і Т-4н. 
Літолого-фаціальна характеристика продуктивних пачок турне вказаного вузла, який знаходиться на границі Срібнянської і Жданівської депресій в Дніпровсько-Донецькій западині (ДДЗ), грунтується на детальному вивченні наявного кернового матеріалу і шліфів.

Продуктивна пачка T-1 має товщину 61, 68, 81, 76 і 75м в Мехедівській свердловині 1, Луценківській 4, Свиридівських 3 і 4 відповідно. 3 неї відібрано лише по одному керну в Мехедівській св. 1, Луценківській 4 і Свиридівській 4, три керни - в Свиридівській 3.

В розрізі Мехедівської св. 1 керн з глибини 3465-3467м представлений аргілітом, в розрізі Луценківської св. 4 (5574-5583м) різноманітними аргілітами та алевролітом, в розрізі Свиридівської св. 3 (5624-5630, 5647-5653, 5681-5686м) - аргілітами, пісковиками і алевролітом, в розрізі Свиридівської св. 4 (5652-5663м) - алевролітом і аргілітом.

В кернах, відібраних з Мехедівської св. 1 і Луценківської 4, алевро-піщані породи відсутні. В керні 49 (5647-5653м) з розрізу Свиридівської св. 3 алевроліт (0,2 м) темно-сірий, кварцовий, міцний, переходить до тонкозернистих пісковиків. В керні 50 (5681-5686м) міститься пісковик (0,2м) сірий, дрібнозернистий, глинистий. В шліфі він має калішпато-кварцовий склад, алевро-псамітову структуру і безладномасивну текстуру. Уламки порід кутасті, цемент поровий каолініт-гідрослюдистий. В ньому $є$ новоутворення стягнень дрібноагрегатного сидериту з овальних зерняток. На ділянках стягнень розвинутий поровий сидеритовий цемент. У верхній частині єдиного керну з глибини 5652-5663м 3 розрізу Свиридівської св. 4 знаходиться прошарок $(0,1 \mathrm{M})$ алевроліта сірого щільного, міцного, зі стилолітами. В шліфі алевроліт неоднорідний, польовошпато-кварцовий (кварцу - 80\%), з безладною, не орієнтованою текстурою, з глинистим, поровим цементом, в якому багато піриту. За рентгено-структурними даними в глинистій фракції алевролітів міститься дисперсна гідрослюда, а також кварц і польовий шпат.

Продуктивна пачка Т-2 має товщину 33, 61, 47, 38, 40 і 42м в Мехедівській свердловині 1, Луценківській 4, Свиридівських 2, 3, 4 і 5 відповідно. 3 неї відібрано лише по одному керну з розрізів свердловин Мехедівська 1, Луценківська 4, Свиридівська 3, в перших двох з яких він представлений аргілітами, а в Свиридівській 3 - аргілітами і вапняком. Алевро-піщані породи у відібраних кернах відсутні.

Продуктивна пачка Т-3 має товщину 90, 61, 64, 74, 32 і 87м в Мехедівській св. 1, Луценківській св. 4, Свиридівських 2, 3, 4, 5 відповідно. 3 неї відібрано три керни з розрізу Мехедівської св. 1, Луценківської 4, Свиридівських 3, 5, чотири керни з розрізу Свиридівської св. 3, один керн з розрізу Свиридівської св. 2, два керни з розрізу Свиридівської св. 4. Керни представлені пісковиками, алевролітами, аргілітами.

В керні 29 з розрізу Мехедівської св. 1 під аргілітом залягають пісковики сірі, дрібнозернисті, слюдисті, міцні, середньо- або крупнозернисті по нашаруванню, алевроліти сірі, слюдисті, міцні.

Верхня частина керну 31 складена аргілітом товщиною 1м, під яким знаходиться 5-метровий пласт пісковика ясно-сірого, від дрібно- до середньозернистого, слюдистого, з рідкісними обвугленими рослинними рештками по нашаруванню, з мікропрошарками глинистої речовини, лінзами чорного аргіліту. Прошарки ясно-сірого пісковика чергуються з прошарками коричнюватого, пористого, пухкого, з запахом вуглеводнів.

На Луценківській площі (свердловина 4) відібрані керни представлені в основному аргілітами 3 прошарками пісковиків. В прошарку з глибини 5677-5685м пісковик дрібнозернистий, темно-сірий, слюдистий, шаруватий. В одному шліфі пісковик середньозернистий, псамітовий, безладномасивний, калішпато-кварцовий з регенераційно-конформним цементом. В іншому шліфі пісковик дрібнозернистий, псамітовий, з слабоорієнтованою текстурою, в основному кварцовий, з поровим дрібноагрегатним каолініт-гідрослюдистим, гніздами сидеритовим, ділянками конформно-регенераційним цементом.

В середній частині керну з інтервалу 5696-5699м знаходиться прошарок (15см) пісковика сірого, дрібнозернистого, слабого. В шліфі пісковик середньозернистий, кварцовий, має псамітову структуру, безладномасивну текстуру, слабообкатані уламки, переважно регенераційно-конформний, реліктами поровий тонкоагрегатний каолініт-гідрослюдистий або крупноагрегатний каолінітовий цемент.

На Свиридівській площі в свердловині 2 відібрано керн з глибини 5812-5827м, який представлений перешаруванням алевро-піщаних і глинистих порід. Мікроскопічне вивчення алевро-піщаних порід свідчить про те, що вони різні. 


\section{В.А. IBАНИШИН}

В одному зі зразків пісковик дрібнозернистий, має псамітову структуру, орієнтовану текстуру, калішпато-кварцовий склад з домішком уламків кремнистої породи, мікрокварцитів, рідкісних лусочок слюд біотиту, серициту, акцесорних мінералів циркону, зеленого турмаліну. Калішпати представлені анортоклазом, частково вивітрілим або заміщеним каолінітом. Тип цементу поровий, склад гідрослюдистий. Окремі зерна мають конформні контакти. Глиниста маса місцями (гніздами) пігментована гідрооксидами заліза і має коричньово-бурий колір.

В другому зразку пісковик поліміктовий (польовошпато-кварцовий), крупнозернистий, псамітовий, з орієнтованою текстурою, рідкісними лусочками слюди біотиту, уламками мікрокварцитів, кремнистого матеріалу, зернами циркону, магнетиту. Трапляються обкатані уламки ефузивної породи. Польові шпати представлені калішпатами і плагіоклазами, частково вивітрілим або заміщеним каолінітом. Уламки зцементовані регенераційно-конформним, кварцовим цементом, з реліктами первинного порового цементу, заповненого гідрослюдою і крупнолускатим каолінітом.

В третьому зразку пісковик різнозернистий, від дрібнозернистого до гравійного, має дрібнокрупнозернисту псамітову структуру, орієнтовану текстуру, польовошпато-кварцовий склад. Польові шпати представлені плагіоклазами, окремі зерна яких вивітрілі, частково або повністю заміщені серицитом, каолінітом. В породі міститься домішок кремнистого матеріалу, мікрокварцитів, рідкісних лусочок біотиту, акцесорних мінералів зеленого турмаліну і циркону.

Алевроліт, який залягає нижче, глинистий, має крупноалевритову структуру з зернами дрібного псаміту, орієнтовану текстуру. В його складі кварц, рідкісні зерна плагіоклазів, які інколи вивітрілі, лусочки слюд серициту, мусковіту,біотиту, уламки кремнистого матеріалу, циркон, зелений турмалін. Трапляються мікролінзи і гнізда пилуватого піриту, фюзенизовані рослинні рештки. Мікротріщинки заповнені вугільним пилом. Зерна зцементовані базальним, рідше поровим, гідрослюдистим цементом.

В нижній частині керну знаходиться пісковик середньозернистий, масивний. Він складається $з$ кварцу, поодиноких зерен плагіоклазів, халцедону, уламків кремнію, мікрокварцитів, рідкісних лусочок біотиту. 3 акцесорних мінералів трапляється бурий турмалін, анатаз. Цемент пісковика поровий і регенераційно-конформний. Первинний поровий цемент крупнолускатий каолінітовий, вторинний карбонатний. Окремі зерна кварцу мають регенераційну облямівку. Теригенний матеріал добре відсортований.

Літолого-фаціальна характеристика пачки Т-3 в розрізі Свиридівської св. 3 грунтується на вивченні кернів з глибини 5757-5758, 5758-5760, 5795-5806, 5806-5816м. Керн з першого інтервалу представлений пісковиками (0,4м) сірими, прошарками коричнювато-сірими, середньо-крупнозернистими, нерівномірноглинистими, які чергуються з чистими і глинистими прошарками, з шаруватістю під кутом 3-50, з слабим запахом вуглеводнів при розколюванні. В шліфі пісковик різнозернистий, переважно середньозернистий, з орієнтованою мікротекстурою, в основному кварцовий, з поодинокими зернами ортоклазу, який побурів, лусочками біотиту і мусковіту, зернами циркону. Тип цементу поровий, склад глинистий, в основному тонкоагрегатний каолініт-гідрослюдистий, частково крупноогрегатний каолінітовий.

Нижче (5758-5760м) залягають пісковики ясно-сірі, в основному середньозернисті, у верхній частині неясношаруваті, в нижній - масивні, середньої міцності, з стилолітами. В шліфі пісковик крупнозернистий, безладномасивний, в основному кварцовий, з зернами каолініту і бурозеленого турмаліну. Цемент переважно поровий, конформно-регенераційний, реліктами в порах тонкоагрегатний каолініт - гідрослюдистий або крупноагрегатний каолінітовий, іноді сферолітовий сидеритовий.

Керн, відібраний з глибини 5795-5806м, складений пісковиками сірими до ясно-сірих, місцями 3 коричнюватим відтінком, масивними, іноді хвилясто-шаруватими, з запахом вуглеводнів, в нижній частині з прошарками (5-10 мм) аргілітів темно-сірих з крупними рослинними рештками. В одному шліфі пісковик різнозернистий (крупно- і середньозернистий). Крупнозернисті різновиди мають базальномасивну текстуру, калішпато-кварцовий склад, з цирконом, переважно конформно-регенераційний цемент, в одних окремих порах з реліктами крупноагрегатного каолінітового, в інших - 3 реліктами тонкоагрегатного каолініт-гідрослюдистого. В окремих порах з'являються новоутворення сидериту. Середньозернисті різновиди мають слабо орієнтовану текстуру, калішпато-кварцовий склад, порово-базальний тонкозернистий сидеритовий, частково сферолітовий цемент. В окремих порах трапляється реліктовий крупноагрегатний каолініт. В іншому зразку пісковик крупнозернистий, 
безладномасивний, переважно кварцовий, з цирконом, в основному з регенераційно-конформним цементом, реліктами в поодиноких порах - каолініт-гідрослюдистим або вторинним сидеритовим.

Нижче в розрізі (5806-5816м) залягають аргіліти, алевроліти, пісковики. Алевроліти темно-сірі, глинисті, слюдисті, з великою кількістю рослинних решток і прошарками сірих і темно-сірих, глинистих пісковиків.В шліфі вони мають псамо-алевритову структуру, орієнтовану текстуру, кварцовий склад, поровий каолініт-гідрослюдистий тонкоагрегатний цемент. Із акцесорних мінералів трапляються поодинокі зерна синьо-зеленої рогової обманки, піроксену чи турмаліну. Сфероліти сидериту рідкісні.

В одному зі зразків пісковик різнозернистий, переважно крупнозернистий, безладномасивний, в основному кварцовий, з зернами калішпатів. Уламки місцями зцементовані конформно-регенераційним, місцями поровим реліктовим крупноагрегатно каолінітовим, рідко сферолітовим сидеритовим цементом. Інший пісковик середньозернистий, слабоорієнтований, місцями масивний, переважно кварцовий, з рідкісними зернами калішпату (ортоклаз) , який побурів. Цемент в ньому в основному конформно-регенераційний, в поодиноким порах реліктовий крупноагрегатний каолінітовий.

В Свиридівській свердловині 4 керн відібрано з глибини 5748-5754 і 5754-5770м. Керн з першого інтервалу складений (зверху вниз) аргілітом, алевролітом, пісковиком.

Алевроліт (0,4м) ясно-сірий, щільний, з відбитками обвугленої рослинності, з дзеркалами сковзання.

Пісковики (1,4м) ясно-сірі, дрібнозернисті, міцні, іноді з паралельною або лінзоподібною шаруватістю, з вуглистою речовиною по нашаруванню, з вуглистими включеннями. В шліфі пісковик дрібнозернистий, псамітовий, масивний, кварцовий. Серед уламків, крім кварцу, є польові шпати, турмалін. Зерна кварцу обкатані, напівобкатані, слабокутасті. Цемент в основному кварцовий, каолінітовий, карбонатний, інкорпораційноконформний, поровий, базальний.

Керн з глибини 5754-5770м представлений пісковиками $(4,4 \mathrm{M})$ і аргілітами $(4,6 \mathrm{M})$.

Пісковики ясно-сірі, дрібно- і крупнозернисті, з вуглистою речовиною в тріщинах, стилолітовими швами, запахом вуглеводнів. В шліфі пісковик різнозернистий, польовошпато-кварцовий (кварц $80 \%$, польові шпати - 15\%). Обкатаність уламків погана, багато регенерованих зерен. Цемент в основному базальний, іноді поровий, за складом переважно карбонатний, кварцовий, каолінітовий. 3 аутигенних мінералів, крім кальциту і каолініту, трапляються ромби доломіту, розсіяні по всьому шліфу, інколи сфери сидериту.

3 пачки Т-3 в Свиридівській свердловині 5 піднято три керни з глибини 5820-5830, 5830-5842, 5900-5909м. Перший і третій керни повністю складені аргілітами. У верхній частині другого керну також знаходяться аргіліти (5,8м), а під ними - пісковики (5,0м) сірі і ясно-сірі, дрібно-середньозернисті, з косою шаруватістю під кутом 450, іноді лінзоподібною, хвилястою, перехресною, в окремих випадках з вуглистою речовиною по нашаруванню, зі стилолітовими швами.

Продуктивна пачка Т-4в має товщину 63, 58, 67, 53, 58 і 46м в Мехедівській св. 1, Луценківській 4, Свиридівських 2, 3, 4, 5 відповідно. 3 неї відібрано один керн з розрізу Мехедівської св. 1, два керни з розрізів Луценківської св. 4, Свиридівських 2, 3, три керни з розрізу Свиридівської св. 4 і п'ять кернів з розрізу Свиридівської св. 5. Керни представлені аргілітами, пісковиками, алевролітами.

В розрізі Мехедівської свердловини 1 пачка в основному глиниста, в середині якої знаходиться пласт пісковика (0,5м) від ясно-сірого до сірого з коричнюватим відтінком, дрібно-середньозернистого, з тріщинами, заповненими темною вуглистою речовиною.

Літолого-фаціальна характеристика пачки Т-4в на Луценківській площі (св. 4) грунтується на результатах вивчення зразків порід з кернів з глибини 5771-5776 і 5785-5793м. Перший з них складений аргілітами, в яких знаходиться прошарок алевроліту кварцового, мікрошаруватого з гострокутними, не обкатаними уламками. Верхня і нижня частини другого керну також складені аргілітом, а між ними залягають прошарки алевролітів і пісковиків, які чергуються. В першому зверху прошарку алевроліти мають лінзоподібну, хвилясту, іноді паралельну, перехресну шаруватість. Пісковики, які їх змінюють, ясно-сірі, дрібнозернисті, з хвилястими мікропрошарками алевроліту, вкрапленнями темної вуглистої речовини. Алевроліти різнозернисті, переважно дрібнозернисті, з поровим глинистим цементом і крупними стягненнями піритизованого кальциту. Пісковики дрібнозернисті, кварцові, з плівчастим глинистим, плямистим карбонатним цементом, а також конформним кварцовим. 
3 розрізу Свиридівської св. 2 відібрано керни з глибини 5884-5904 і 5904-5919м. Перший з них представлений вапняками (7,4M), прошарками аргілітів, а також алевролітами $(0,4 \mathrm{M})$ сірими, дуже глинистими, з відбітками рослинних решток.

В шліфі алевроліт дуже глинистий, має крупноалевритову структуру, орієнтовану, гніздоподібну, лінзоподібну-мікрошарувату текстуру, складається з кварцу, плагіоклазу, часто з вивітрілих, заміщених каолінітом, уламків кремнистої породи, мікрокварцитів, лусочок біотиту, сидериту, акцесорних мінералів циркону, турмаліну, анатазу, рудного магнениту. Цемент гідрослюдистий, поровий, з конформними контактами окремих зерен.

Керн з глибини 5904-5919м складають пісковики ясно-сірі до білих, цукроподібні, дрібно-крупнозернисті, з гніздами вуглистої речовини, внизу (0,3м) пісковики сірі, розбиті на гострокутні шматки. В шліфі пісковик крупнозернистий, з орієнтованою текстурою, польовошпато-кварцовий, з уламками кремнистого матеріалу, мікрокварцитів, акцесорних мінералів бурого турмаліну і анатазу. В складі польових шпатів плагіоклаз і анортоклаз частково вивітрілі або заміщені каолінітом. Цемент переважно регенераційно-конформний кварцовий, з реліктами первинного порового крупнолускатого каолінітового, нерідко в порах розвинутий карбонатний цемент.

В розрізі Свиридівської св. 3 пачка Т-4в у верхній частині (5838-5871м) складається з пісковиків у перешаруванні з аргілітами, в нижній (5882-5892м) - з сірих алевролітів.

В одному з зразків пісковики ясно-сірі, різнозернисті. В шліфі пісковик середньозернистий, безладномасивний, переважно кварцовий, з зернами калішпатів - мікрокліну, ортоклазу, олігоклазу, стилолітами, переважно поровим, середньоагрегатним каолінітовим, тонкоагрегатним каолініт-гідрослюдистим цементом.

В іншому зразку пісковики ясно-сірі, дрібнозернисті, кварцові, середньої міцності. В шліфі пісковик середньозернистий, має слабоорієнтовану, майже безладномасивну текстуру, переважно кварцовий склад, з зернами калішпатів - мікрокліну і бурого ортоклазу, а також акцесорних мінералів - зеленої і зеленувато-синьої рогової обманки, епідоту, турмаліну. Цемент пісковиків переважно конформно-регенераційний. Іноді в порах трапляються релікти тонкоагрегатного каолініт-гідрослюдистого і середньоагрегатного каолінітового цементу.

Алевроліти сірі, опіщанені, перехідні до тонкозернистих пісковиків, масивні, слюдисті, в окремих різновидах з обвугленими рослинними рештками. В шліфі алевроліти глинисті, мають пело-алевритову структуру, орієнтовану текстуру, кварцовий склад, з поодинокими кремнієвими уламками, катунчиками аргілітів, уривками органічних решток. Цемент поровий, тонкоагрегатний каолініт-гідрослюдистий.

В розрізі Свиридівської св. 4 з пачки Т-4в відібрано три керни з глибини 5816-5831, 5855-5867 і 5867-5879м.

Верхня частина першого керну складена аргілітами, нижня - пісковиками темно-сірими, дрібнозернистими, з включеннями вуглистої речовини, які місцями змінюються пісковиками ясно-сірими, дрібнозернистими, карбонатними. Вони мають лінзоподібну, паралельну, перехресну шаруватість. В шліфі пісковик дрібнозернистий, з карбонатним первинним цементом, який становить 40\% породи. Уламки кварцу не обкатані, напівобкатані.

Другий керн у верхній частині також представлений аргілітом (0,7м). Під ним залягають пісковики $(1,8 \mathrm{M})$ крупнозернисті, слюдисті, тріщинні, з великими (до 5мм) гравійними зернами кварцу, включеннями вуглистої речовини і глинистої гальки. В шліфі пісковик крупнозернистий, з окремими зернами розміром понад 2мм. Уламки кварцу, польового шпату не обкатані. Цементу в породі 15\%, він карбонатний.

Нижче залягають пісковики (3,0 м) дрібнозернисті, міцні, з косою, лінзоподібною і паралельною шаруватістю, вуглистою речовиною по нашаруванню, рідкісними стилолітовими швами, з прошарками (10 см) аргіліту. В шліфі пісковик різнозернистий, польовошпато-кварцовий, збагачений розсіяним дрібним піритом. Уламки порід не відсортовані, не обкатані. Цемент - каолінітовий, сидеритовий.

Пісковики підстилаються аргілітами (4,4 м).

Третій керн складений (зверху вниз) аргілітами, пісковиками, аргілітами. Пісковики (4,5 м) сірі і ясно-сірі, іноді темно-сірі, дрібнозернисті, в прошарках середньо- і крупнозернисті, місцями глинисті, з паралельною, лінзоподібною, косою, переривчастою шаруватістю, вуглистою речовиною. В шліфі, в одному зразку, пісковик різнозернистий, переважно крупнозернистий, кварцовий. Зерна кварцу ка- 
таклазовані, розбиті тріщинами. Текстура слабо орієнтована (за рахунок зорієнтованих в один бік крупних подовжених зерен кварцу). В другому зразку пісковик переважно крупнозернистий, неоднорідний, кварцовий. Уламки не відсортовані, не обкатані.

Літолого-фаціальна характеристика пачки Т-4в в розрізі Свиридівської св. 5 грунтується на вивченні кернів з глибини 5909-5919, 5919-5929, 5929-5940, 5940-5950 і 5950-5960м. Тобто тут маємо випадок суцільного відбору керну з інтервалу 5909-5960м. Як і в розрізах інших свердловин, товща розкрита свердловиною 5, складається з аргілітів і пісковиків, які перешаровуються.

В першому керні під аргілітами розкриті пісковики (1,0 м) темно-сірі, дрібно-зернисті, вверху глинисті, з різнокосою, місцями паралельною, лінзо- і дугоподібною шаруватістю. Трапляються сірі і ясно-сірі різновиди. В темно-сірих пісковиках міститься вугілля. Другий керн вверху також складений аргілітами (6,0 м), під якими залягають пісковики, що продовжуються і в наступньому, третьому, керні. Іх загальна товщина становить 9,5м, вони не однорідні, різні. У верхній частині піщаної товщі пісковики (2,5 м) сірі, дрібнозернисті, міцні, внизу з прошарками (20 см) крупнозернистих, до гравелістих, з різноманітною шаруватістю (лінзоподібною, косою, місцями паралельною, іноді хвилястою), стилолітовими швами, запахом вуглеводнів. Верхню частину третього керну складають пісковики (7,0 м) ясно-сірі, дрібнозернисті, міцні, з прошарками крупнозернистих, з паралельною, лінзоподібною, слабо хвилястою шаруватістю, стилолітовими швами, запахом вуглеводнів, відбитками обвугленої кори. До низу пісковики змінюють свій колір на темно-сірий. В нижній частині четвертого керну знаходяться пісковики (4,5 м) ясно-сірі, різнозернисті (середньо-крупнозернисті), з косою, перехресною, лінзоподібною, іноді паралельною шаруватістю, кварцові, слюдисті, з плямами вуглистої речовини, стилолітами. Пісковики підстилаються аргілітами п'ятого керну, а їх змінюють пісковики (3,4 м) ясно-сірі, дрібно-середньозернисті, з дугоподібною, хвилястою, іноді паралельною, перехресною, лінзоподібною шаруватістю, кварцові, щільні, міцні, з відбитками обвуглених стебел і кори, стилолітовими швами.

Продуктивна пачка T-4н має товщину 41, 43, 64, 33, 46 і 52м в Мехедівській св. 1, Луценківській 4, Свиридівських 2, 3, 4, 5 відповідно. 3 неї відібрано два керни з розрізу Мехедівської св. 1, шість кернів з розрізів Луценківської св. 4 і Свиридівської 5, чотири керни з розрізу Свиридівської св. 2, три керни з розрізів Свиридівських св. 3, 4. Керни представлені аргілітами, пісковиками, алевролітами.

Літолого-фаціальна характеристика пачки Т-4н в Мехедівській св. 1 грунтується на вивченні кернів з глибини 5692-5709 і 5709-5726м. Перший з них складений у верхній частині аргілітом (5,0 м). Під аргілітами залягають пісковики (4,6 м) сірі до ясно-сірих, дрібнозернисті, міцні, з слабопаралельнохвилястю шаруватістю, дрібним вуглистим детритом, вуглистою речовиною в тріщинах, численними стилолітовими швами. Нижче знаходиться алевроліт (0,4 м) міцний, слюдистий, з псамо-алевритовою структурою, слабо орієнтованою текстурою, калішпато-кварцовим складом, глинистим (гідрослюдистим) цементом.

Верхню частину другого керну також складають аргіліти (6,0 м), а під ними знаходяться пісковики (2,5 м) темно-сірі, що іноді розпадаються на плитки, місцями з коричнюватим відтінком, стилолітовими швами, вуглистими включеннями.

В Луценківській св. 4 керн відібрано з глибини 5793-5800, 5800-5806, 5806-5813, 5813-5818, 5825-5827, 5839-5842м. Він складений переважно аргілітами. Алевроліти і пісковики мають незначну товщину. Мікроскопічне вивчення алевролітів свідчить, що вони перехідні до дрібнозернистих пісковиків, мають псамо-алевритову структуру, базальну текстуру, кварцовий склад, з зернами частково каолінізованих каолішпатів, поровий тонкоагрегатий каолініт - гідрослюдистий цемент.

Пісковики сірі, слюдисті, середньої міцності, зі слабою косою, майже паралельною, шаруватістю. В шліфі пісковик середньозернистий, безладномасивний, переважно кварцовий, з зернами калішпатів бурого кольору, в основному конформно-регенераційним, в окремих порах реліктовим крупноагрегатним каолінітовим цементом.

В Свиридівській св. 2 керн відібрано з глибин 5924-5938, 5938-5951, 5970-5984, 5984-5994м. Як і в розрізі Луценкіської св. 4 тут пачка Т-4н глиниста, але в ній є вапняки в інтервалі 5984-5994м. В нижній частині пачки залягають пісковики сірі, від дрібно- до крупнозернистих, з слабохвилястою шаруватістю, вуглистою речовиною. Нижче іх змінюють алевроліти сірі, міцні, з частими дзеркалами сковзання, обвугленими рослинними рештками. Під ними знаходяться пісковики сірі, дрібно-серед- 
ньозернисті, з паралельною шаруватістю і вуглистою речовиною у вигляді прошарків, каолінітовим цементом, а також пісковики ясно-сірі, крупнозернисті.

Алевроліт в шліфі поліміктовий. Уламки представлені кварцом, польовими шпатами (плагіоклази і калішпати), мусковітом і біотитом. Трапляються уламки мікрокварцитів, ефузивів. Із акцесорних мінералів є циркон (поодинокі зерна). Цемент глинистий (каолінітовий, місцями вуглисто-гідрослюдисто-каолінітовий). Текстура породи мікролінзоподібношарувата. Глинистий матеріал розподілений нерівномірно.

В розрізі Свиридівської св. 3 пачка глиниста. В кернах з глибини 5892-5898, 5898-5905, 59055912м переважають аргіліти. В середній частині пачки є пісковики (0,2 м) сірі і ясно-сірі, дрібнозернисті, щільні, з включеннями вуглистої речовини, з запахом вуглеводнів на свіжому зламі. Пісковики з інтервалу 5905-5912м ясно-сірі, дрібно- і середньозернисті, рідко гравійні. В одному шліфі пісковик має середньозернисту псамітову структуру, слабо орієнтовану текстуру, польовошпато-кварцовий склад. Польові шпати калієві і плагіоклаз-олігоклазові. Уламки кутасті і напівобкатані, добре відсортовані. Цемент поровий, тонкоагрегатний каолініт-гідрослюдистий. В другому шліфі пісковик різнозернистий (середньо-крупно-грубозернистий), безладномасивний, калішпато-кварцовий, з поровим тонкоагрегатним каолініт-гідрослюдистим цементом. На окремих ділянках в грубозернистих пісковиках трапляються мікролінзочки аргілітів алевритистих, збагачених геліфікованою органікою і пилуватим піритом.

В Свиридівській св. 4 керн відібрано з глибин 5890-5901, 5901-5918, 5918-5934м. Перші два керни складені переважно алевро-піщаними породами, а третій - аргілітами. Тобто літологічно пачка відрізняється від розрізів Свиридівських св. 2, 3.

Пісковики з першого керну (5890-5901м) ясно-сірі, середньо-крупнозернисті, міцні, щільні, з стилолітовими швами, включеннями вуглистої речовини лінзоподібної форми. В шліфі пісковик дрібнозернистий, олігоміктовий. Зерна кварцу майже одного розміру, але різної форми, напівобкатані. Серед уламків є чисті, не зачеплені вторинними змінами, польові шпати. Цементу в породі - 10-15\%. Він поровий, глинисто-карбонатний, нерівномірний, не розкристалізований, частково корозійний. Під пісковиками залягають алевроліти (5,6 м) ясно-сірі, міцні, щільні, які іноді переходять в дрібнозернистий пісковик з сидеритовими конкреціями і тріщинами, заповненими кальцитом, рідкісними відбитками решток рослин. Подібні алевроліти складають також верхню частину керну з інтервалу 59015918м.

В Свиридіській св. 5 з пачки Т-4н відібрано керни з глибини 5960-5971, 5971-5983, 5983-5990, 5990-5996, 5996-6009, 6009-6023м, тобто тут ми маємо безперервну 63-метрову товщу, охарактеризовану керном. Вміст алевро-піщаних порід в пачці ще вищий, ніж в розрізі Свиридівської св. 4. Суттєвими є вміст аргілітів лише в керні з інтервалу 5996-6009 і 6009-6023м.

Верхня частина першого керну представлена пісковиками (5,2 м) ясно-сірими, дрібнозернистими, щільними, міцними, з неправильною лінзоподібною, косою шаруватістю, іноді з включеннями вуглистої речовини. В нижній частині трапляються прошарки пісковиків з зеленуватим відтінком і відбитками фауни.

В дев'яти метрах другого керна перешаровуються пісковики, алевроліти, аргіліти, знову пісковики. Верхня частина керну складена пісковиками сірими, ясно-сірими, середньо-крупнозернистими до гравелітових, з плямами вуглистої речовини, крупною паралельною і перехресною шаруватістю. Внизу керна пісковики сірі, з лінзоподібною, інколи паралельною, перехресною, дугоподібною шаруватістю, з вуглистими включеннями і без них, з стилолітовими швами. Подібні пісковики складають керни з глибини 5983-5990, 5990-5996 і верхню частину керну з глибини 5996-6009м, в якому ще $€$ гравелітові прошарки. В керні з інтервалу 6009-6023м під аргілітами залягають пісковики (1,4 м) ясно-сірі, різнозернисті, від дрібно- до крупнозернистих, міцні, іноді з включеннями вуглистої речовини. Ïх змінюють пісковики (2,8 м), але темно-сірі, до зеленуватих, тонкозернисті.

Підсумовуючи викладене можна зробити такі висновки:

1. Накопичення турнейських відкладів відбувалося в умовах дуже частої зміни знаку тектонічних рухів, які відбилися на структурі, текстурі і мінеральному складі піщано-алевритових порід. В надзвичайно вузьких інтервалах розрізу відбувалася зміна дрібнозернистих пісковиків середньо-, крупно-, гравелітовими, і навпаки. 
2. Уламковий матеріал пісковиків і алевролітів переважно не відсортований і не обкатаний, що може свідчати про близкість джерел зносу матеріалу і дуже швидкий його перенос.

3. Численні відбитки обвуглених решток рослин, стебел, кори, наявність вуглистої речовини в алевро-піщаних породах, різноманітна шаруватість (коса, хвиляста, дуго- і лінзоподібна, перехресна), різнозернистість говорить про те, що накопичення осадків відбувалося переважно в континентальних умовах (дельта, авандельта, озера, болота), які іноді, на короткий час, змінювалися прибережно-морськими, морськими.

1. Заварицкий А.Н. Введение в петрографию осадочных пород. - ГОНТИ: 1932. - 132с.

2. Жемчужников Ю.А. К вопросу о понятиях «структура и текстура» для осадочных пород (по поводу статьи Ю.Г.Старицкого) // Зап. Всесоюз. минерал. общества. - 1956. - Вып. 1, вторая серия, ч. 85. - С. 21-27.

The Chernigov Branch of the UkrSLEl, Chernigov, Ukraine

Чернігівське відділення УкрДГРІ, м. Чернігів, Україна 